\title{
An investigation into the development and progressive adaptation of graduate attributes in tourism programmes
}

\author{
Louise Bellew \\ Technological University Dublin, louise.bellew@tudublin.ie \\ Odette Gabaudan \\ Technological University Dublin, odette.gabaudan@tudublin.ie
}

Follow this and additional works at: https://arrow.tudublin.ie/tfschhmtart

Part of the Curriculum and Instruction Commons, Higher Education Commons, Social and Behavioral Sciences Commons, and the Tourism and Travel Commons

\section{Recommended Citation}

Louise Bellew \& Odette Gabaudan (2017) An investigation into the development and progressive adaptation of graduate attributes in tourism programmes, Journal of Teaching in Travel \& Tourism, 17:3, 139-158, DOI: 10.1080/15313220.2017.1318104

This Article is brought to you for free and open access by the School of Tourism \& Hospitality Management at ARROW@TU Dublin. It has been accepted for inclusion in Articles by an authorized administrator of ARROW@TU Dublin. For more information, please contact arrow.admin@tudublin.ie, aisling.coyne@tudublin.ie, gerard.connolly@tudublin.ie.

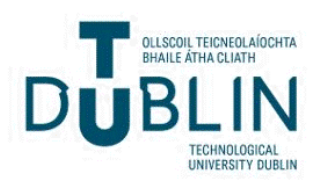




\section{An investigation into the development and progressive adaptation of graduate attributes in tourism programmes}

\section{Louise Bellew \& Odette Gabaudan}

To cite this article: Louise Bellew \& Odette Gabaudan (2017) An investigation into the development and progressive adaptation of graduate attributes in tourism programmes, Journal of Teaching in Travel \& Tourism, 17:3, 139-158, DOI: 10.1080/15313220.2017.1318104

To link to this article: https://doi.org/10.1080/15313220.2017.1318104

曲 Published online: 04 May 2017.

Submit your article to this journal $\pi$

III Article views: 200

Q View related articles ๔

View Crossmark data 


\title{
An investigation into the development and progressive adaptation of graduate attributes in tourism programmes
}

\author{
Louise Bellew and Odette Gabaudan ${ }^{\mathrm{b}}$
}

aschool of Hospitality Management \& Tourism, DIT, Dublin, Ireland; 'bSchool of Languages, Law and Social Sciences, DIT, Dublin, Ireland

\begin{abstract}
As higher education institutes are embracing the notion of graduate attributes, it has become highly desirable to embed these attributes within programmes. This study proposes to investigate students' views of recently identified graduate attributes in the Dublin Institute of Technology (Ireland), and how they perceive their development and application in their tourism programme. The study supports the idea of the importance of placement in the progressive adaptation of learning and in translating the conception of attributes. While students strongly believe that graduate attributes are developed through the placement experience, it is equally important to embed and strengthen the visibility of the graduate attributes building blocks throughout the programme.
\end{abstract}

\section{ARTICLE HISTORY}

Received 8 September 2016 Accepted 6 April 2017

\section{KEYWORDS}

Graduate attributes; placement; progressive adaptation; tourism education; curriculum development

\section{Introduction}

In recent years, graduate attributes have been the focus of much attention. Within higher education institutes, they are increasingly used in the design and review of curricula, and in communications to students and staff. To those outside the institute, they contribute to communicating the core values that underpin an institute's educational philosophy. As a result, higher education institutes in Ireland are developing policies and rolling out implementation plans around their chosen set of graduate attributes. Curriculum design plays a key role in the development of a particular set of graduate attributes in students. At the heart of sound curriculum design is a progressive adaptation towards higher levels of achievement. This study explores the linkages between students' placement experience and the integration of progressive adaptation in curriculum design with a view to achieve a particular set of graduate attributes. The focus of the study is on two of the tourism programmes delivered in the Dublin Institute of Technology (DIT). One involves students of a Tourism Management Bachelor degree while the other is a programme for students who have chosen to study a Bachelor in Languages and International Tourism. Graduate attributes under investigation were identified through two employer graduate attributes workshops prior to the study.

CONTACT Louise Bellew louise.bellew@dit.ie ESchool of Hospitality Management \& Tourism, DIT, Cathal Brugha Street, Dublin 1, Ireland

(c) 2017 Informa UK Limited, trading as Taylor \& Francis Group 
Participating employers represented a number of sectors including tourism, event, hospitality, food, marketing and communications. This research draws on the students' narratives and experiences surrounding the development of graduate attributes, up to and including placement.

\section{Context of this study}

Upon graduation, students who enter the job market are faced with fulfilling employers' expectations of certain graduate attributes. Graduate attributes are the qualities, skills and understandings a university community agrees its students should develop during their time with the educational institute. Therefore, these attributes shape the contribution graduates are able to make not only to their profession but also to society as they become agents of social good in an unknown future (Bowden, Hart, King, Trigwell, \& Watts, 2000).

Higher education institutes increasingly take a lead in ensuring that students are supported in the development of the institute's chosen graduate attributes and that they are built into the curriculum. In 2013, the DIT established a set of institute-wide graduate attributes that students develop through the compulsory components of their programme of study, through specialist options integrated within their programme (e.g., internships, research-based activities) or through extracurricular activities within the institute (engagement with clubs and societies). The DIT graduate attributes fall within five broad categories, as follows: engaged, enterprising, enquiry based, effective and expert in a chosen discipline (Harvey, Kavanagh, Kilmartin, O'Connor, O'Leary \& O'Rourke, 2015). As is often the case, institute-wide graduate attributes tend to be rather generic and need to be more closely defined for particular programmes within a School. With this in mind, in 2014, two employer workshops explored a potentially relevant set of graduate attributes. These include being a reflective practitioner, an active team player, a good communicator, a motivated self-starter and having an ethical approach. It is this particular set of five attributes along with the notion of progressive adaptation that will serve as a thread for the present study.

\section{Literature review}

Resulting from an increased focus on employability and mobility, many higher education institutes have devoted considerable attention to graduate attributes. If the terminology and assumptions around graduate attributes vary across higher education institutes, they all find their origin in the Bologna process. Indeed, under the Higher European Education Area, the concepts of qualifications frameworks, learning outcomes, mobility, quality enhancement and graduate employability are core. ${ }^{1}$

Heretofore, graduate attributes were an implicit outcome of students' higher education experience. In more recent years, the emphasis is on identifying key graduate attributes that an institute prides itself in developing in its students. It is important to distinguish learning outcomes, inherent to all pedagogical activities, from graduate attributes, a more holistic set of qualities developed through a broader range of curricular and extracurricular experiences (Barrie, 2004; Cranney, Turnbull, Provost, Martin, Katsikitis, White, Varcin, 2009). Graduate attributes can be characterised as being generic and transcending disciplinary content 
knowledge (Barrie, 2006). They focus on the outcome of years of university learning experiences and cannot be acquired over a short space of time. Graduate attributes are always context dependent (Barrie, 2004). In this respect, Yorke and Harvey (2005) mention the importance of taking into account the "situatedness" of cognition for graduate attributes, and warn against an exclusive focus on the assessment of skills. Other key components of graduate attributes identified by Yorke and Harvey $(2005$, p.48) are efficacy beliefs and metacognitive activities such as reflective practice. Developing these attributes is a slow process that requires repetition and progressive adaptation to the next level of complexity.

The hierarchical typology proposed by Barrie (2006) helps categorising graduate attributes. At a basic level are the precursor conceptions of attributes that enable students to get through their university years. These precursor attributes are abilities students have at entry level. The next level is characterised by complementary conceptions of attributes. Here, the existing abilities complement the learning that takes place in university. The third level is the translation conception of attributes. It involves the application of knowledge acquired during university education. The highest level of attributes is the enabling conception. It has the potential of transforming knowledge, creating new ones and transforming the individual. Barrie's typology is clearly useful in gaining a deeper understanding of graduate attribute dynamics. In the context of a 3 or 4-year degree, it can be assumed that any set of graduate attributes draws on all four levels of the typology and concentrates on the two higher levels as student's progress through their university years.

In researching a satisfactory process for embedding graduate attributes in teaching practices, Barrie (2004) found that a consultation process combined with a discipline approach to the selection and interpretation of graduate attributes allowed for statements on graduate attributes that became more meaningful to all stakeholders. In this consultative approach, the generic university's attributes are the starting point to a process of understanding the relevance of any given attribute within a particular discipline. Following this consultation phase, the identified graduate attributes can then be mapped against the curriculum.

However, mapping used as a simple audit tends to promote an ineffective and superficial approach towards the development of graduate attributes (Barrie, 2004; Sumsion \& Goodfellow, 2004). In some of the studies reviewed, the number of core attributes for a particular programme was reduced in an attempt to make the consultation or the assessment process more manageable (Cranney et al., 2009; Easa, 2013). In one instance, each core attribute is measured by a number of indicators that draws on the knowledge, skills, attitudes or behaviours that students are expected to demonstrate (Easa, 2013). In another study, the attributes come with a list of corresponding learning outcomes generated through a consultation process with stakeholders (Cranney et al., 2009). A recurrent recommendation is that the inclusion of graduate attributes in course content or assessment should not stand in parallel to other core course requirements but be embedded in the curriculum.

Special attention should also be given to the relationship between disciplinary content and the acquisition of graduate attributes, though not at the expense of disciplinary content (Ballard \& Clancy, 1995). Instead, departments and course teams should endeavour to "translate" or "enable" conceptions of attributes (Barrie, 2004) by identifying suitable contexts and learning experiences in other core course requirements. In this 
respect, Kolb, Rubin and Osland (2000, p.70) argued that there are two goals in the experiential learning process: one is to learn the specifics of a particular subject matter, the other is to learn about one's own strengths and weaknesses as a learner, or in other words, learning how to learn from experience (cited in Zopiatis \& Constanti, 2012, p.45). Cheong, Yahya, Lor Shen, and Yen Yen (2013) believe that placing a higher emphasis on interning provides students with opportunities to gain first-hand experiences of the dayto-day operations in their field. This ultimately better equips students with a range of valuable skills and attributes upon their graduation.

More specifically in the hospitality sector, Yiu and Law $(2012$, p. 384) cite various studies which extol the many benefits of the placement experience. It represents the "very pinnacle" of experiential learning for hospitality students, contributing to the student's development both personally and professionally. Keogh, Maguire and O'Donoghue (2015) in their recent conference paper also highlight the importance of the role played by placement in delivering critical graduate attributes. Yiu and Law (2012) contend that the benefits enjoyed by students participating in internships include a better understanding and knowledge of the tasks and practices performed by industry professionals, enhanced employment and professional growth opportunities, networking with potential employers, learning new concepts, gaining experiences, improving self-confidence, exposure to management activities and developing the competencies and skills demanded by the industry. The authors further suggest that a primary goal of hospitality internship programmes is to prepare students to become reflective practitioners who can make good decisions in real life, based on a sound understanding of theory.

The literature reviewed underpins a greater understanding of graduate attributes and how they can best be integrated into the curriculum. Prior research also extols the benefits of experiential learning in developing graduate attributes. However, while publications around graduate attributes or placement abound, the dearth of literature is notable when it comes to investigations in the area of graduate attributes and the role of placements in the tourism sector. In addition, few publications if any consider the extent to which progressive adaptation takes place in the development of graduate attributes. This study brings new insights into the manner in which these skills and attributes can best be developed, so that students are progressively equipped with a relevant set of graduate attributes.

\section{Methodology}

Recent literature has shown the significant focus on the area of graduate attributes and how it can be evidenced in the curriculum and in programme outcomes. As the School of Hospitality Management and Tourism in the DIT endeavours to identify a set of relevant graduate attributes for its programmes, the researchers are motivated to understand from the students' perspective, how and where the selected attributes for the purposes of this research are developed at programmatic level and identify any potential gaps in fostering these attributes. Informed by the academic literature, the following research objectives for the study were set:

- Seek to understand the level of the students' awareness of graduate attributes.

- Evaluate the importance of placement in delivering programme-related graduate attributes. 
- Reveal the issues of integration and curriculum design in order to fulfil the development of programme-related graduate attributes in a progressive manner, both prior to and during placement.

In line with a phenomenological approach, the researchers seek to understand (Saunders, Lewis, \& Thornhill, 2016) the subjective reality of the students so as to make sense of their reflections and interpretations in relation to the development of graduate attributes. The central methodology is qualitative with small sample sizes. This affords the opportunity to probe deeply to reveal the understanding of the fostering and development of graduate attributes in the tourism programmes.

However, as the concept of a specific set of graduate attributes was relatively new to the School, and to the students, the researchers wanted to explore the topic by first getting a measure of students' understanding and experience of the selected graduate attributes. A questionnaire was designed to include a range of statements or indicators developed specifically for this study. Each statement is in line with one of the graduate attributes (reflective practitioner, an active team player, a good communicator, a motivated self-starter and having an ethical approach) and the notion of progressive adaptation. The aim was to gauge from the students' responses, the stage in the curriculum at which the learning experience is taking place. Statements were developed arising from the literature (Rees, Forbes, \& Kubler, 2006) and from transcriptions of the employers' focus group that took place in the School prior to this study. A selection of open questions also allowed students to raise added issues or insights. The closed statements were formulated around the particular graduate attributes. The questionnaire was anonymous and was distributed in class to all final year students of both programmes, at the beginning of the academic year, and shortly after they had returned from placement. Specifically, the questionnaires sought information on their awareness of graduate attributes, their level of work experience prior to placement and their experience of graduate attributes while on placement (Appendix 1). A total of 45 questionnaires were completed, with 43 usable questionnaires obtained. Data from the questionnaires were analysed using Excel. Having gained an initial insight as to where and when graduate attributes were developed, the researchers wanted to further explore these issues through a student focus group.

An open invitation was issued to all students on both programmes to participate in the focus group which took place in December 2015. Eight students volunteered to participate. The six themes (five graduate attributes along with the notion of progressive adaptation) formed the basis of the semi-structured focus group (Appendix 2), and the session lasted approximately $1 \mathrm{~h} 30 \mathrm{~min}$. Participation was good in this self-selected group with active discussion taking place. At the outset of the focus group, the terminology used to identify the five key graduate attributes, along with the notion of progressive adaptation, was explained to students as follows. The motivated self-starter attribute is concerned with an individual's drive and enthusiasm to be part of the placement organisation. The communication attribute considers verbal communication, body language, written communication, e-mail etiquette and the importance of communication within the team. The ethical attribute allows students to relate to issues such as data protection, health and safety, integrity, honesty. The team player attribute explores the ability to work as a team member, the "fit" within the team and communication within the team. The reflective practitioner 
attribute delves into the act required by students to internalise the learning, considering their actions and evaluating their resulting success or failure. The researchers engaged in dialogue with the students though endeavouring not to bias the research.

In terms of data collection, the focus group findings were analysed and discussed under the six emergent themes and in light of the reviewed literature. As for the questionnaire findings, they were summarised and analysed using frequencies of variables by drawing up frequency distribution tables for Questions 5, 8 and 9.

For Question 8, students' scores are reported in Table 1 which is based on first and second preferences only, as these are more statistically significant. This table shows three set of scores, avoiding any instances of double counting. The first column totals the number of students who scored college as their first or second preferred learning environment for a given graduate attribute. The third column totals the number of students who scored work as their first or second preferred learning environment for a given graduate attribute. The second column totals the number of students who placed their first and second preferences in both work and college-based environments.

Questions 5 and 9 were based on a Likert scale. Results for each statement combined "very much disagree" and "disagree" responses on one hand and "very much agree" and "agree" responses on the other hand. During the discussion of the findings, results are expressed as percentages.

Overall the results of the questionnaires and the focus group gave some key comparative findings and provided valuable insights to the research question. Indeed, data emerging out of the initial questionnaire prompted the deeper questioning of how the development of graduate attributes might be perceived in different areas of the programme. Consequently, the theme of "progressive adaptation" could be explored in greater depth along with the various graduate attributes. The researchers were curious to see how students perceived the transformation of knowledge and when or if progressive adaptation addressed the issue of exactly when the learning first took place and how or if this developed over time.

Ethical issues were given due consideration. For both the focus group and the questionnaire, participants provided their informed consent and confidentiality was assured. Questionnaires were self-administered and anonymous; the researchers were not able to identify the participants in the study. The names of focus group participants were changed to protect their identity. The main ethical issue of this research related to information disclosed by participants during the focus group. Would the students feel obliged to respond positively when the session was conducted by two lecturers? Reflexivity was at the heart of the researchers' concerns who are both lecturers on the tourism programmes. Their familiarity with the students could result in the latter being more comfortable in disclosing information in the focus groups and questionnaires. However, students might also respond with what they think the researchers wanted to hear. Another possible negative side of researchers being directly involved in the study is that they might be less objective as a result of socialising into the organisation.

\section{Findings and analysis}

Preliminary insights from the survey set out some of the students' main thoughts on graduate attributes, which were then followed by deeper insights from the focus group. 


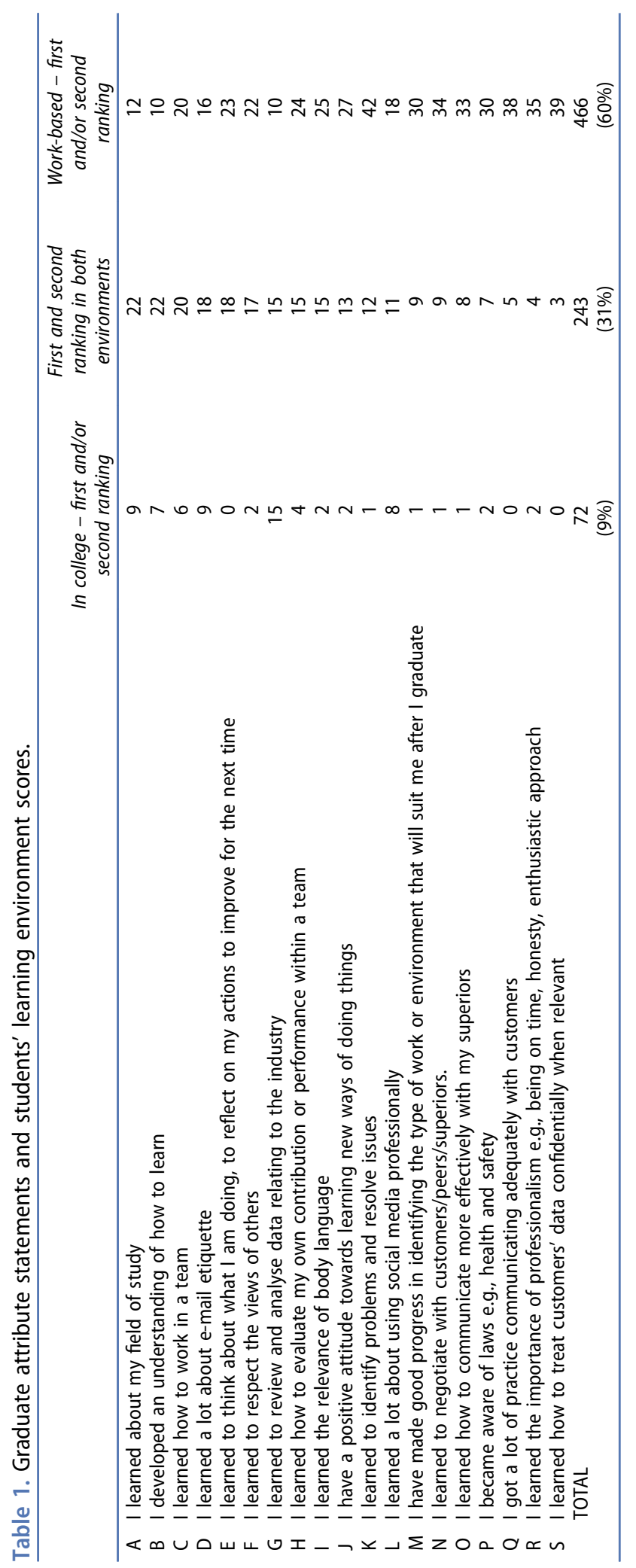


It was clear that students were broadly unfamiliar with the actual term graduate attributes but of those who were, they recall learning of specific graduate attributes in the pre-placement workshop, and more explicitly on placement (Figure 1).

Once students were asked to categorise where they learned about specific graduate attributes, there was a clear leaning towards the "active learning" environment of the placement experience (Figure 2, as a visual summary of Table 1), with the application and transformation of knowledge mostly put into practice during this period of time. The situatedness of cognition (Yorke \& Harvey, 2005) needs consideration here, where students are in the final stages of their programme and the translation and enabling conceptions occur (Barrie, 2004). This finding motivated researchers to probe students' understanding of the attribution of graduate attributes, and ascertain if and where the

\section{Have you heard of the term "graduate attributes"? If so, where?}

On placement $11 \%$

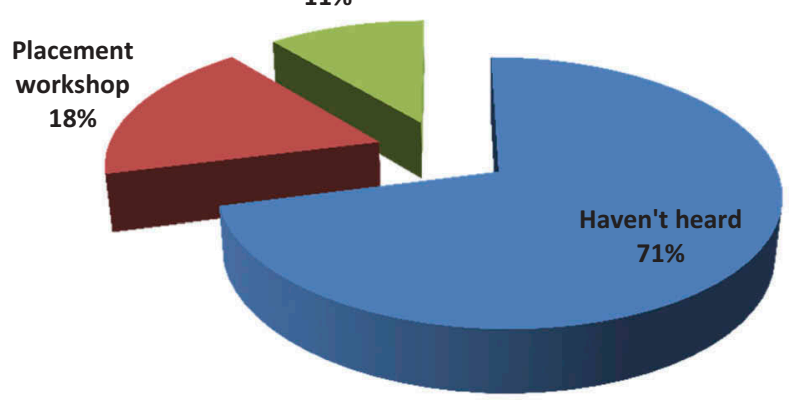

Figure 1. Students' awareness of the term "graduate attributes".

Where did the learning take place?

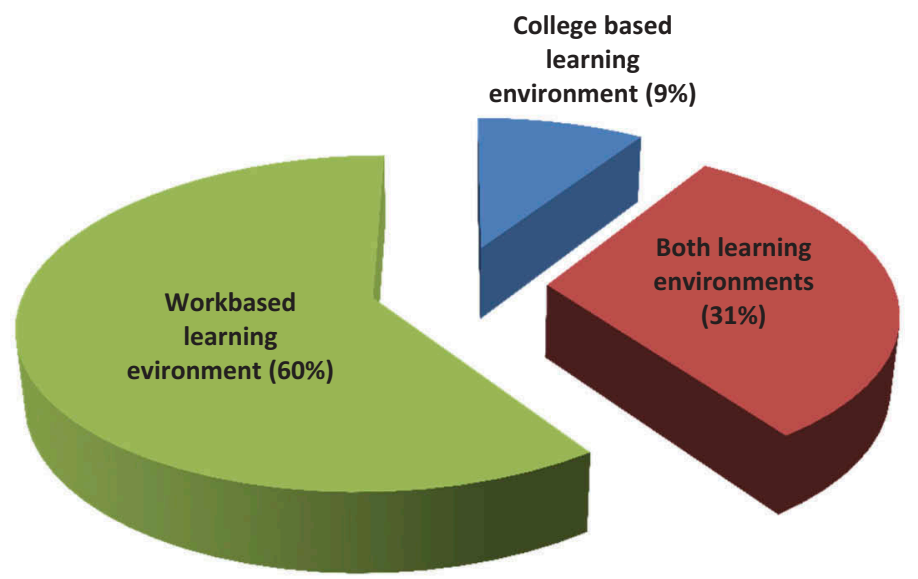

Figure 2. Where did the learning take place? 


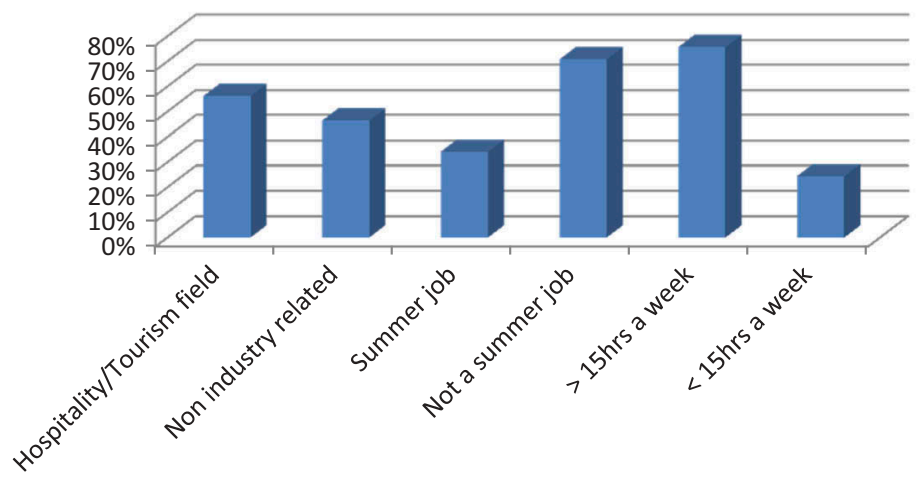

Figure 3. Work experience activity prior to placement.

tacit and explicit learning building blocks of graduate attributes began in earlier stages of the programme.

The majority (95.3\% based on the results of Question 3) of those surveyed had already gained work experience prior to placement, whether in a tourism or nontourism-related sector (Figure 3). Notably over $70 \%$ of these students worked more than $15 \mathrm{~h}$ a week, during term time. Here, for many, the complementary conceptions of attributes (Barrie, 2004) were of benefit to students, in advance of their work experience on placement.

The next section discusses results under each of the six themes (five graduate attributes and progressive adaptation).

\section{The active team player graduate attribute}

The questionnaire results identified placement as a key learning environment for teamwork, with 95\% (Question 9f) of students surveyed considering the placement experience as a means of developing their ability to see situations from an alternative member's viewpoint. However, a significant number of students rate highly both college and work-based learning environments in terms of learning how to work in a team (Table 1, statement C). The focus group discussion revealed that teamwork was also developed in the preceding years of the programmes in the academic environment, though perhaps more tacitly than in the professional work-based environment. With reference to years 1 and 2, one of the students, Stephen, stated "You get an idea of what kind of people you are good with. Personality yes, but also the way they work, we work and how it all works together". Students intimated that the teamwork skills they learned prior to and during placement, were supporting teamwork in their final year of the programme, post internship.

Interestingly, views from students in the focus group diverged in terms of the team player element in an academic setting and in the workplace. Stephen believes "attitudes, perceptions and approaches towards group work are similar whether in college or in a placement". In contrast, Charles argues that ...

There is a huge difference between college assignments and assignments in a placement. In the placement, there was quite a large workforce, 200 people. There was training, and a 
specific way, not of thinking but a specific way of doing things, how you do the check-in etc. So it harmonises quite well. When you do a group assignment, I can want to do something completely different to someone else. That can clash. If I want to do something completely different in a team in work, it doesn't go well because you are going against what you are trained to do. In college work, (...) your style of writing, your opinions are a lot more significant than when you are working in a team in a work placement. There is a training element and you have to respect that. It is more homogenous. In an assignment it can be difficult to get your opinion across to someone else who may have a stronger personality. In the workplace it is easier to overcome that dynamic than in college.

Training is task based; everybody has a role to play in the team whereas for group assignments, students have to figure out what their role is in the group. While students' views may differ, it can be argued that both experiences are equally beneficial in building team player capabilities.

\section{The reflective practitioner graduate attribute}

Primary research is in line with Yiu and Law (2012) or Keogh et al. (2015) where students noted the value of both college and work-based learning environments in developing a sense of self-reflection and learning how to learn (Table 1, statement B). Graduates who are reflective practitioners consider their actions and evaluate their resulting success or failure. As Stephen points out, it is also about being aware of one's strengths and weaknesses, building on the first and addressing the latter as one tries to meet or even exceed the standards that are expected of them.

I made it my business to make sure I was exceeding those standards so I wasn't really reflecting on my strengths, but I was constantly reflecting on my weaknesses, I am very critical of my own performance.

Charles explains that during their placement, students received a work placement appraisal, with a rating from excellent to poor for the various tasks that were performed. The quality of mentoring and personal guidance varied among the group from good to poor. "My mentor was fantastic. She always told me if I did something well or bad and how it would affect me and my future. That's how good a guidance I got" (Charles).

During the focus group, Tony conveyed that the reflective practitioner attribute is developed more through the placement than during college years. While he acknowledged that feedback on performance in college assignments is similar to feedback received during placement, he also suggested most students admit not paying much heed to feedback received on assignments during their first and second undergraduate years. However, Charles qualified Tony's views by explaining that "personal feedback through individual meetings and one to one guidance seems to be most effective".

The focus group revealed that students were aware of their weaknesses but that the placement allowed them the opportunity to address those. A strong sense of selfawareness was evident from one student in particular - Colin, a mature student who had experience in the workplace and had clearly identified issues, and was actively trying to address them. The opportunity to identify problems and resolve issues was also clearly reflected in the survey (Table 1, statement K) with a particularly high score for 
work-based learning. Students are definitely more aware of reflection through their performance in placement.

\section{The ethical graduate attribute}

Students surveyed identified strongly with the workplace rather than the collegebased environment to learn about ethical behaviour, dealing with issues such as confidentiality (Table 1, statement S), professionalism (Table 1, statement R) or health and safety compliance (Table 1, statement P). During the focus group, students' opinions were mixed on how well prepared they were to deal with ethical issues during their placement. Odile referred to an incident during her placement where she wrongly promoted one product over another to her customers. Her mishandling of the situation had negative repercussions for her and her company. She felt she had not been properly trained or briefed and "there were big consequences and you weren't aware of that beforehand". Stephen reinforced Odile's experience by explaining that the company where he did his placement put a lot of emphasis on marketing compliance training, "there was a huge emphasis on that, a lot of training in terms of marketing compliance, it was at the forefront of what we had to do". Aoife on the other hand, referred to the relevance of health and safety procedures as she was at the forefront of a health and safety inspector's visit. While Stephen believes they are ill-prepared for ethical awareness in their first two years in college and argues for the inclusion of a module on ethics, Charles believes that a good dose of common sense when accidents or incidents happen is essential.

Overall, the discussion points to the need for a greater preparation in the early years of the programme. Interestingly, first and second year modules delivered to the 2014/ 2015 cohorts had already been reviewed to include a greater focus on the ethics and governance areas. While common sense may act as a "precursor attribute" (Barrie, 2006), formalised college-based learning in areas such as corporate governance, health and safety, marketing compliance would help in building "complementary conception of attributes" (Barrie, 2006) in the ethics area.

\section{The motivated self-starter graduate attribute}

The motivated self-starter attribute is particularly salient in the context of the placement experience. Students rated placement highly as a place to show initiative $93 \%$ (Question 9b). They also generally displayed a strong level of enthusiasm with $90 \%$ (Question 5c) highly motivated at the idea of getting hands-on experience in their field of study.

During the focus group, Stephen links motivation and enthusiasm for the task at hand to the notion of empowerment and the handover of responsibility. Charles and Adele feel enthusiasm tends to be generated by the external environment. In their case, motivation was facilitated by a positive company culture and constructive engagement with lecturers. "Definitely, we love some classes, we feel we have a say in the class, some classes we hate because we feel we don't have a say" (Adele). Tony agreed that external factors such as organisational culture can motivate the employee "I think if you are 
made feel part of the organisation, the enthusiasm will be there straight away". Astrid adds that internal factors such as personal interest in an assignment topic or a task in the workplace can drive motivation.

\section{The excellent communicator graduate attribute}

As results show, this attribute appears to be mostly developed during placement. Students in the focus group differentiate between communication skills developed in college and in the workplace. In years 1 and 2 of the programme, students surveyed explain that the communication attribute is developed when they learn about academic communication skills such as e-mail etiquette (Table 1, statement D), writing reports or giving presentations. Holly explains "Year 1 Applied Communication prepared us to write reports, whereas on placement it was more professional communication, e-mails and phone calls, dealing with customers". On the other hand, students who completed their placement in France believe they were well prepared in college to address customers in a formal manner as they had the benefit of a module that focuses on professional communication through French. All interviewees consider placement as a turning point in terms of gaining confidence in their professional communication skills as they interact both verbally and in writing with customers and their superiors. This view concurs with the high score of statements $\mathrm{N}, \mathrm{O}, \mathrm{Q}$ in Table 1. Although students have learned much about communication and social media on placement, surprisingly many $(55.8 \%$ Question 9d) had yet to connect with employers on Linkedln. In concluding the interview, participants reflected on the fact that their desire to participate in the focus group showed how far they have come in their ability to reflect and communicate.

\section{Progressive adaptation}

We now consider the extent to which progressive adaptation towards the attainment of key graduate attributes is built into the programme. We also explore the contexts in which the selected attributes have been developed.

Respondents believe there is a good balance between the academic and work-based learning environments in laying down the foundations for building knowledge about their field of study (Table 1, statement A) and for helping them foster the ability to review and analyse industry-related data (Table 1, statement $G$ ). Students did not highly rate their part-time job as an environment to develop industry knowledge. Neither did they feel that a part-time job could replace the experience of a structured, performancebased placement in which reflection is an important aspect. However, they did consider a part-time job as a good foundation to develop their practical skill sets. It helps students to come out of their shell, gain confidence and deal with customers in a professional manner. It means that during the placement "you aren't just experiencing it for the first time, and this gives you an inner confidence, it shows you can be given more responsibility, and be less naïve" (Jenny).

Progression of learning is particularly steep during placement with $81 \%$ agreeing or very much agreeing that they first felt out of depth, but that by the end of their 
6 months placement, they had built on their knowledge and experience (Question 9a). In this respect, they note the significant role played by the mentor in providing positive feedback (60\% - Question 9h) and on shining a light on student's weaknesses $(55.8 \%$ Question 9g). Interestingly, progressive adaptation resonated strongly with students in terms of communication skills. Stephen, in the Tourism Management programme explains:

People are afraid to communicate, before in Year 1, I don't know what to say, I was reserved, I was afraid to communicate, but there is no need to be and that's what I learned in my placement (...). Communicating was a big part of what I had to do for the placement. Year 1 and 2 were good to prepare myself for presentations, getting to be comfortable speaking in front of someone. On my placement, it is something I had to do and now I can talk to hundreds or thousands of people at a time, and it's possibly the thing that was recognised most (...) back here in college like tutors is that they say oh my god who are you, you weren't this person when you were here.

Similarly, the International Tourism and Languages programme includes a year 2 module to prepare students for professional communication in a francophone environment, just prior to departure on Erasmus. "I think college prepared us. In France the way you have to address an adult is different than younger people. I think in college we were well prepared for that" (Odile).

All interviewees who had a positive experience during their placement consider it as the cornerstone in promoting communication skills, building motivation and contributing to their overall personal and professional development, as illustrated by Charles' quote: "yes I see this miniature size of me and a graph steadily going up".

\section{Limitations}

As a limitation to this exploratory study on the roll-out of graduate attributes in all programmes, it is noteworthy that the attributes under current consideration are those initially identified by one particular group of stakeholders, namely employers representing a range of sectors. Input on the selection of relevant graduate attributes from students or academics was beyond the scope of this study. As a result, the attribute of disciplinary expertise, core to academics' objectives and integral to the majority of higher education institutes (Green; Hammer \& Star, 2009), was not taken into consideration. Employers, on the other hand, tend to take this attribute for granted. A follow-up study would need to include both academics and students in the selection of key attributes for a particular programme. In addition, a longitudinal approach following a comprehensive embedding through a school and programme review process, would provide more reliable quantitative findings and further enrich the qualitative results.

\section{Discussion and conclusions}

Each of the initial research objectives will now be discussed in light of the findings, the analysis and the literature.

The first research objective was to seek to understand the level of the students' awareness of graduate attributes. As seen in the literature and in the context of this study, graduate attributes are the subject of much consideration in higher education institutes, 
particularly those based in the Anglo-Saxon world. Yet, it is evident that students in the programmes under scrutiny in this study have a poor understanding of the concept of graduate attributes. The minority who were acquainted with the terminology associate the concept with the professional rather than the academic environment. This research highlights, as is suggested in the literature (Barrie, 2004), that graduate attributes need to be clearly embedded and mapped out in a programme so that students develop an awareness around key attributes for their programme. The ideal opportunity to achieve the embedding of attributes would be in the context of a programmatic review. Academics would then be in a better position to articulate learning outcomes of their modules in light of specific graduate attributes and in turn students could leverage their understanding and experience of graduate attributes to potential employers. A means of explicitly expressing the selected set of graduate attributes for a given programme is to include it in all documentation related to the programme and the placement such as student handbooks, preparation workshops, industry evaluation reports or students' reflective placement reports. Indeed a discussion on key programmatic graduate attributes could already be introduced during the year 1 induction schedule, to further support a satisfactory awareness around graduate attributes among both staff and students.

The second research objective sought to evaluate the importance of placement in delivering programme-related graduate attributes. Students who participated in this study are unequivocally enthusiastic about work-based learning with the vast majority considering placement to be of greater value than a previous job experience (even when the job is in their chosen industry) or than the college-based learning environment. Students believe all five graduate attributes are greatly developed during their placement thus concurring with a number of previous research studies (Ballard \& Clancy, 1995; Cheong et al., 2013; Keogh et al., 2015). It is in the later years of the programme that much of the translation and enabling conceptions (Barrie, 2004, 2006) of graduate attributes are attained. In their third year of the programme, and particularly while on placement, students assert their individual responsibility and learn to develop their reflective abilities. This in turn helps them convey an explicit articulation of their learning, and is in line with Yiu and Law (2012) who contend that industry-related placement is at the pinnacle of experiential learning and is critical in delivering graduate attributes (Keogh et al., 2015). In the majority of questions, students ranked placement as being of greater benefit than the academic learning environment. An underlying reason may be the vocational and applied nature of our programmes which attracts students who are generally more interested in an experiential learning environment, rather than an academic environment only. Be that as it may, students' insights relate very closely to Cheong et al. (2013) who suggest that a higher emphasis should be put on placement as it plays a crucial role in the development of a range of valuable skills and attributes. Students also acknowledge the benefit of placement in allowing them to "learn how to learn" (Kolb et al., 2000, p.45).

The final research objective focused on revealing the issues of integration and curriculum design in order to fulfil the development of graduate attributes in a progressive manner, both prior and during placement. The findings clearly reveal some deficiencies in years 1 and 2 of the curriculum in relation to the progressive adaptation towards the development of graduate attributes. Firstly, programmes would benefit from a review underpinned by the integration of a set of relevant graduate attributes, generated through a consultative process with all relevant 
stakeholders including not only employers but also students and academics (Cranney et al., 2009). The involvement of academics would ensure that the selected graduate attributes for a programme would include disciplinary content, an essential component of any curriculum design. Mindful of the concerns raised by a number of authors (Barrie, 2004; Sumsion \& Goodfellow, 2004; Cranney et al., 2009; Easa, 2013), mapping graduate attributes to each year's learning outcomes would certainly support building a progressive adaptation to their development. Secondly, as placement plays a critical role in students' transformative learning and knowledge (Barrie, 2006), employers need clear guidance in order to facilitate the progressive attainment of graduate attributes. Thirdly, based on Barrie's (2004) suggestion that course teams should endeavour to "translate" or "enable" conception of attributes by identifying suitable contexts and learning experiences on course requirements other than discipline-based ones, the integration of more problem-based learning during years 1 and 2 would support students in the development of self-starter skills, teamwork, communication and reflective practice. The inclusion of a number of hours of experiential learning (e.g. 200 hours) during years 1 or 2 would help to expose students to the industry of their choice, apply or translate the theoretical learning in a professional environment, reflect on their experiences and therefore feed into the situatedness of cognition as referred to by Yorke and Harvey (2005).

This study has sought to address the gap in the literature in relation to the linkages between graduate attributes, tourism education and placement. It has revealed the importance of embedding graduate attributes into a tourism programme as otherwise students don't seem to take full cognisance of the value of the early stages of the programme that support the situational learning during placement. Furthermore, mapping graduate attributes to programmatic learning outcomes is essential for the integration of graduate attributes and for the laying of a clear path for academics, placement employers and students, towards the progressive achievement of graduate attributes. While it may appear that progressive adaptation is taking place implicitly, this study has shown the relevance of explicitly embedding and articulating in programme documentation the progressive attainment of graduate attributes throughout the curriculum and even more particularly in the early years of the programme as these are the building blocks of latter development.

\section{Note}

1. http://www.ehea.info/

\section{Disclosure statement}

No potential conflict of interest was reported by the authors.

\section{References}

Ballard, B., \& Clancy, J. (1995). Generic skills in the context of higher education. Higher Education Research and Development, 14(2), 155-166. doi:10.1080/0729436950140202 
Barrie, S.C. (2006). Understanding what we mean by the generic attributes of graduates. Higher Education, 51, 215-241. doi:10.1007/s10734-004-6384-7

Barrie, S.C. (2004). A research-based approach to generic graduate attributes policy. Higher Education Research \& Development, 23(3), 261-275. doi:10.1080/0729436042000235391

Bowden, J., Hart, G., King, B., Trigwell, K., \& Watts, O. (2000). Generic capabilities of ATN university graduates. Canberra: Australian Government Department of Education, Training and Youth Affairs.

Cheong, A.L.H., Yahya, N.B., Lor Shen, Q., \& Yen Yen, A. (2013). Internship experience: An in-depth interview among interns at a business school of a malaysian private higher learning institution. Procedia Social and Behavioural Sciences, 123, 333-343. Retrieved from: http://www.sciencedir ect.com/science/article/pii/S1877042814014694. doi:10.1016/j.sbspro.2014.01.1431

Cranney, J., Turnbull, C., Provost, S.C., Martin, F., Katsikitis, M., White, F.A., Varcin, K.J. (2009). Graduate attributes of the 4-year Australian undergraduate psychology program. Australian Psychologist, 44(4), 253-262. doi:10.1080/00050060903037268

Easa, S.M. (2013). Framework and guidelines for graduate attribute assessment in engineering education. Canadian Journal of Civil Engineering, 40(6), 547-556. doi:10.1139/cjce-2012-0485

Green, W., Hammer, S., \& Star, C. (2009). Facing up to the challenge: Why is it so hard to develop graduate attributes? Higher Education Research and Development, 28(1), 17-29. doi:10.1080/ 07294360802444339

Harvey, J., Kavanagh, A., Kilmartin, D., O'Connor, R., O'Leary, C., \& O'Rourke, K. (2015, May 28-29). Constructing a practice informed graduate attributes toolkit: Built in not bolt-on. EdTech 2015. Ireland: University of Limerick.

Keogh, J., Maguire, T., \& O'Donoghue, J. (2015). Graduate work-readiness in the 21st. century. Proceedings from Higher Education in Transformation Conference, Dublin, Ireland, 385-395.

Kolb, D., Rubin, I., \& Osland, J. (2000). Organizational behaviour, an experiential approach (7th ed.). New York: Prentice Hall

Rees, C., Forbes, P., \& Kubler, B. (2006). Student employability profiles - A guide for higher education practitioners. The Higher Education Academy. Retrieved from: https://www.heacad emy.ac.uk/system/files/student_employability_profiles_apr07.pdf

Saunders, M., Lewis, P., \& Thornhill, A. (2016). Research methods for business students (7 $7^{\text {th }}$ ed.). New York: Pearson Education.

Sumsion, J., \& Goodfellow, J. (2004). Identifying generic skills through curriculum mapping: A critical evaluation. Higher Education Research \& Development, 23(3), 329-346. doi:10.1080/ 0729436042000235436

Yiu, M., \& Law, R. (2012). A review of hospitality internship: different perspectives of students, employers, and educators. Journal of Teaching in Travel \& Tourism, 12(4), 377-402. doi:10.1080/ 15313220.2012 .729459

Yorke, M., \& Harvey, L. (2005). Graduate attributes and their development. New Directions for Institutional Research, 128, 41-58. doi:10.1002/ir.162

Zopiatis, A., \& Constanti, P. (2012). Managing hospitality internship practices: A conceptual framework. Journal of Hospitality \& Tourism Education, 24(1), 44-51. doi:10.1080/ 10963758.2012.10696661 


\section{Appendix 1. Questionnaire}

What is this survey about?

You have just returned from your placement. This brief questionnaire aims to gather information on the skills and attributes you think you have developed prior to and during your placement. We would like to reflect on what skills and attributes you developed, and these findings will inform future programme content and structure. It will also form the basis for a paper on the role of progressive adaption in the context of a placement. This questionnaire is anonymous. Your honesty, consideration and participation are greatly appreciated.

Many thanks.

Please complete the table below indicating your programme title and year of study.

Section one: some general information about your awareness of graduate attributes.

1. Have you heard of the term graduate attributes? (Please circle as appropriate)

YesNo

2. If you answered yes,

Programme

Year

a. In what context have you heard of it? (Please circle as appropriate)

Placement preparation workshop

On placement

Other, please specify

b. Could you please provide some information on what the term "graduate attributes" means to you?

Section two: prior to placement.

3. Prior to your placement, did you have any work experience?

(Please circle as appropriate)

Yes No

4. If you answered yes,

a. Was your work experience in the hospitality/tourism field?

(Please circle as appropriate)

Yes No

b. Was it a summer job?

(Please circle as appropriate)

Yes No

c. How many hours a week did it entail?

(Please circle as appropriate)

More than $15 \mathrm{~h}$ a week Less than $15 \mathrm{~h}$ a week

5. Your perception of going on placement - for each statement, please tick the most appropriate box

Section three: on placement.

6. Where did your placement take place? (Please tick as appropriate) 
7. How did you find your placement organisation? (Please tick as appropriate)

\begin{tabular}{|c|c|c|c|c|c|c|c|}
\hline & & $\begin{array}{r}\text { Very much } \\
\text { disagree }\end{array}$ & Disagree & $\begin{array}{r}\text { Neither agree } \\
\text { or disagree }\end{array}$ & Agree & $\begin{array}{l}\text { Very much } \\
\text { agree }\end{array}$ & $\mathrm{N} / \mathrm{A}$ \\
\hline$a$ & $\begin{array}{l}\text { I felt enthusiastic at the } \\
\text { idea of doing a } \\
\text { placement }\end{array}$ & & & & & & \\
\hline$b$ & $\begin{array}{l}\text { I felt the college prepared } \\
\text { me enough for the } \\
\text { placement }\end{array}$ & & & & & & \\
\hline c & $\begin{array}{l}\text { I was keen to get hands- } \\
\text { on experience in the } \\
\text { field of my study }\end{array}$ & & & & & & \\
\hline$d$ & $\begin{array}{l}\text { My part-time job (if } \\
\text { relevant) prepared me } \\
\text { for my placement }\end{array}$ & & & & & & \\
\hline
\end{tabular}

8. For each of the statements on the left, in which learning environment did you learn most? Please rank the most relevant boxes with 1 being where you learned the most and 4

Ireland

The United Kingdom

The United States

Australia

Other non-English-speaking country (please specify)

a Through DIT Placement Officer

b Through family/personal contacts

c Through cold calling

being where you learned the least. If you feel a particular statement does not apply, tick the "Not applicable" option.

9. Reflect on the statements below and tick the most appropriate box to the right.

10. Can you sum up your participation in internship in one sentence?

\begin{tabular}{|c|c|c|c|c|c|c|}
\hline & & \multicolumn{5}{|c|}{ Learning environments } \\
\hline & & $\begin{array}{l}\text { In years } 1 \text { and } \\
2 \text { of college }\end{array}$ & $\begin{array}{l}\text { Through } \\
\text { preparatory } \\
\text { placement } \\
\text { workshops }\end{array}$ & $\begin{array}{l}\text { During my } \\
\text { placement }\end{array}$ & $\begin{array}{l}\text { Through a } \\
\text { previous job } \\
\text { experience }\end{array}$ & $\begin{array}{c}\text { Not } \\
\text { applicable }\end{array}$ \\
\hline a & $\begin{array}{l}\text { I learned a lot about e-mail } \\
\text { etiquette }\end{array}$ & & & & & \\
\hline b & $\begin{array}{l}\text { I learned a lot about using } \\
\text { social media } \\
\text { professionally }\end{array}$ & & & & & \\
\hline c & $\begin{array}{l}\text { I got a lot of practice } \\
\text { communicating } \\
\text { adequately with } \\
\text { customers }\end{array}$ & & & & & \\
\hline$d$ & $\begin{array}{l}\text { I learned the relevance of } \\
\text { body language }\end{array}$ & & & & & \\
\hline e & $\begin{array}{l}\text { I learned how to work in a } \\
\text { team }\end{array}$ & & & & & \\
\hline$f$ & $\begin{array}{l}\text { I learned how to evaluate } \\
\text { my own contribution or } \\
\text { performance within a } \\
\text { team }\end{array}$ & & & & & \\
\hline
\end{tabular}


Learning environments

\begin{tabular}{|c|c|c|c|c|c|c|}
\hline & & \multicolumn{5}{|c|}{ Learning environments } \\
\hline & & $\begin{array}{l}\text { In years } 1 \text { and } \\
2 \text { of college }\end{array}$ & $\begin{array}{l}\text { Through } \\
\text { preparatory } \\
\text { placement } \\
\text { workshops }\end{array}$ & $\begin{array}{l}\text { During my } \\
\text { placement }\end{array}$ & $\begin{array}{c}\text { Through a } \\
\text { previous job } \\
\text { experience }\end{array}$ & $\begin{array}{c}\text { Not } \\
\text { applicable }\end{array}$ \\
\hline g & $\begin{array}{l}\text { I learned to think about } \\
\text { what I am doing, to } \\
\text { reflect on my actions to } \\
\text { improve for the next } \\
\text { time }\end{array}$ & & & & & \\
\hline $\mathrm{h}$ & $\begin{array}{l}\text { I developed an } \\
\text { understanding of how to } \\
\text { learn }\end{array}$ & & & & & \\
\hline i & $\begin{array}{l}\text { I learned how to treat } \\
\text { customers' data } \\
\text { confidentially when } \\
\text { relevant }\end{array}$ & & & & & \\
\hline j & $\begin{array}{l}\text { I have a positive attitude } \\
\text { towards learning new } \\
\text { ways of doing things }\end{array}$ & & & & & \\
\hline k & $\begin{array}{l}\text { I learned the importance of } \\
\text { professionalism e.g., } \\
\text { being on time, honesty, } \\
\text { enthusiastic approach }\end{array}$ & & & & & \\
\hline I & $\begin{array}{l}\text { I have made good progress } \\
\text { in identifying the type of } \\
\text { work or environment } \\
\text { that will suit me after I } \\
\text { graduate }\end{array}$ & & & & & \\
\hline $\mathrm{m}$ & $\begin{array}{l}\text { I became aware of laws } \\
\text { e.g., health and safety }\end{array}$ & & & & & \\
\hline $\mathrm{n}$ & $\begin{array}{l}\text { I learned about my field of } \\
\text { study }\end{array}$ & & & & & \\
\hline 0 & $\begin{array}{l}\text { I learned to review and } \\
\text { analyse data relating to } \\
\text { the industry }\end{array}$ & & & & & \\
\hline $\mathrm{p}$ & $\begin{array}{l}\text { I learned to identify } \\
\text { problems and resolve } \\
\text { issues }\end{array}$ & & & & & \\
\hline$q$ & $\begin{array}{l}\text { I learned how to } \\
\text { communicate more } \\
\text { effectively with my } \\
\text { superiors }\end{array}$ & & & & & \\
\hline$r$ & $\begin{array}{l}\text { I learned to respect the } \\
\text { views of others }\end{array}$ & & & & & \\
\hline s & $\begin{array}{l}\text { I learned to negotiate with } \\
\text { customers/peers/ } \\
\text { superiors }\end{array}$ & & & & & \\
\hline
\end{tabular}




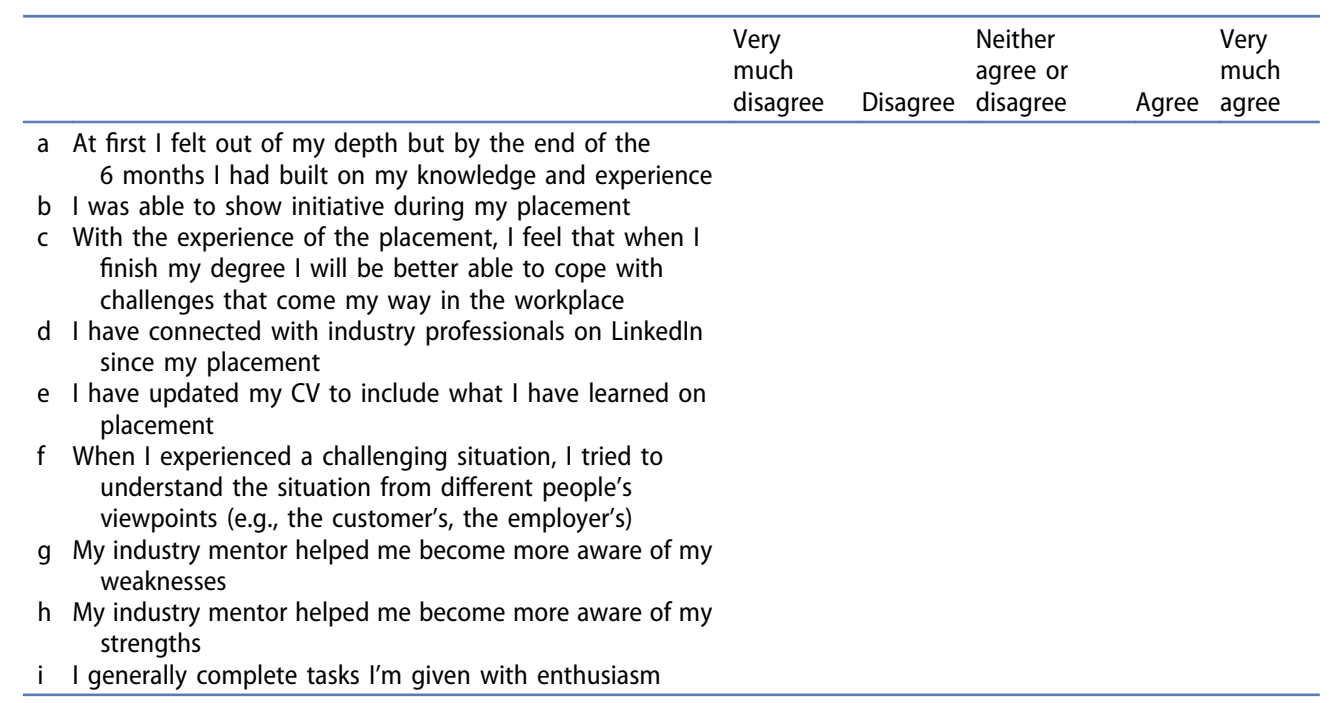

\section{Have you any other comments to make about placement?}

\section{Thank you for your contribution.}

\section{Appendix 2. Focus Group Questions}

The themes under analysis below were presented to the student focus group and they were asked to reflect broadly on their experience of how and when these GA were developed in their programme.

List of graduate attributes:

- Active team player

- Reflective practitioner

- Ethical approach

- Motivated self-starter

- Excellent communicator

Progressive adaptation of those graduate attributes throughout the programme. 